\title{
Farewell to Arms
}

\section{Richard F Walker D}

Scientific Research and Discovery, ProSoma Therapeutics LLC, Clearwater, FL, 33765, USA
Correspondence: Richard F Walker Scientific Research and Discovery, ProSoma Therapeutics LLC, 1932 Dew Street, Unit II, Clearwater, FL, 33765, USA

Tel + I 727648279 |

Email drrwalker@gmail.com
This article was published in the following Dove Press journal:

Clinical Interventions in Aging
Throughout 2020, the COVID-19 virus has dominated, demanded, and consumed constant attention, disrupted lives, caused governmental chaos, distracted from creative thought, and even killed many citizens of the Earth. The coming of 2021 brings with it hopes that the rapid and recent development of a vaccine will finally conquer the scourge of this pandemic. Thus, I foresee the New Year as a time of renewed health, and a return to productive intellectual and philosophical focus, reorganization, growth, and transition. In light of that optimism, I would like to take this opportunity to wish you all a healthy, prosperous and Happy New Year, and also to announce that after almost 15 years of devoted service to Clinical Interventions in Aging (CIA), I will be now be focusing my full-time efforts upon completion of a scientific project that has consumed me throughout the extent of my scientific career. Accordingly, I am transferring my editorial responsibilities for CIA to the very worthy and capable hands of Professor Nandu Goswami, PhD. While adding his new responsibilities at CIA, Dr. Goswami will continue to maintain his position as Acting Chair of Physiology and Head of the research group "Gravitational Physiology, Aging and Medicine", at the Medical University of Graz, Austria. More can be read of Dr. Goswami's accomplishments on the Editorial Board members' page at https://www.dovepress.com/journal-editor-clinical-interventions-in-aging-eic4. Within it is mentioned that Dr. Goswami "has been with CIA right from its humble beginnings", which indeed he has. The idea of creating a scientific journal that was more "applied" clinically to expand our abilities to manage problems of human aging rather than to explore basic research for future therapies was born during a serendipitous meeting that I had with Mr. Tim Hill at Tampa International Airport, USA, in 2005. At the time, Tim was Publisher of Dove Medical Press. We were previously unknown to each other, so while having to wait for our connections, we initiated a conversation in the lounge, and over a pint of beer discovered that we might collaborate on a common project. At the time, I was a university professor with research interests, federal grants, and many publications in aging, but still seeking other challenging interests, whereas he wished to expand the peer-reviewed offerings of Dove Medical Press. We collaborated and were successful in that effort, as CIA was first published in 2006. It rapidly gained recognition and now has a respectable Impact Factor of 3.023. CIA, as an asset of Dove Press, was subsequently purchased by the British firm Informa PLC in 2017, where the journal's international standing in aging care will continue to grow under the capable leadership of Dr. Goswami. So, in closing, I wish to thank all those 
administrators, staff editors, reviewers, and contributors without whose support CIA would just be a possibility rather than the valuable reality it has become.

\section{Disclosure}

The author reports no conflicts of interest in this work.

\section{Publish your work in this journal}

Clinical Interventions in Aging is an international, peer-reviewed journal focusing on evidence-based reports on the value or lack thereof of treatments intended to prevent or delay the onset of maladaptive correlates of aging in human beings. This journal is indexed on PubMed Central, MedLine, CAS, Scopus and the Elsevier
Bibliographic databases. The manuscript management system is completely online and includes a very quick and fair peer-review system, which is all easy to use. Visit http://www.dovepress.com/ testimonials.php to read real quotes from published authors. 